\title{
What can Attachment Based Family Therapy Offer Depressed and Suicidal Youth?
}

\author{
By Pravin Israel ${ }^{1}$, Guy S Diamond ${ }^{2}$, Johan Siqveland ${ }^{1} \&$ Gary M Diamond ${ }^{3}$
}

Youth suicide is the third leading cause of death among youth (10-19 years), yet few treatments have been tested or proven effective for this population. Interventions that have been tested are usually individual focused therapies. However, studies consistently show family relationships as an important risk and protective factor for suicidal ideation and behavior. This paper reviews the theoretical and empirical support for Attachment Based Family Therapy (ABFT) - a manualized, empirically-based, brief psychotherapy model designed and developed specifically to treat suicidal and depressed youth. ABFT draws from interpersonal theories that suggest the quality of interpersonal relationships in the family play an important role in the development, maintenance, and relapse of depression and suicidal behavior. The treatment targets key relationship processes such as parental availability and emotional attunement and helps youth revise their negative expectancies for parental availability. This is accomplished by discussing core attachment ruptures, as a means of resolving conflicts, improving communication, problem-solving, and affect regulation. The treatment manual is organized around five systematic therapeutic tasks that provide structure, focus, and goals for the therapy. Four treatment studies suggest that ABFT is a promising empirically supported treatment for suicidal youth.

\section{Introduction}

Throughout the world suicide is the third leading cause of death among 10-19 year olds and a major public concern. In Norway, 69 people aged 15-24 died by suicide in 2009 (The Norwegian Institute of Public Health, 2010). Internationally, $20 \%$ of teenagers seriously consider killing themselves and $5 \%$ to $8 \%$ attempt suicide (AACAP, 2001; Grunbaum et al., 2002). Surprisingly, there are few well done intervention studies for youth suicidal behavior, and in most of these studies, the experimental treatment has not been much better than control (Spirto et al., 2002). In fact, a recent meta-analysis of Cognitive Behavioral Therapy (CBT) for youth suicide found no significant effect of CBT for suicide in this age group (Tarrier et al., 2008). Clearly, there is a need to consider alternative interventions.

Surprisingly, few treatment studies have examined family interventions for this population (see Harrington et al., 1998 and Huey et al., 2004). Yet, research on youth suicide consistently identifies family factors as an important risk and protective factor for suicidal ideation and behavior (henceforth called suicidal behavior). Unlike adults, the family context is highly influential and inescapable. Youth suicidal ideation and attempts are more frequent in families characterized as low in cohesion and parental responsiveness and high in conflict (Beautrais et al., 1996; Brent et al., 1994; Fergusson et al., 2000; Kurtz \& Derevensky, 1993). Prospective and cross-sectional studies of both community and clinical samples also have linked parental criticism, emotional unresponsiveness, lack of care and support, rejection and control to youth suicidal ideation and attempts (Connor $\&$ Rueter, 2006; Kerr et .al., 2006; see Wagner et al, 2003 for review). Brent and colleagues (1988) found that 20\% of youth suicides and $50 \%$ of non-fatal suicide attempts were directly preceded by conflict with parents. For some youth, these negative family factors may be the cause of suicide or merely provide the unstable and unsupportive context to fuel youth suicide. But in either case, interventions that impove this development cocoon, might be a promising means of reducing this serious public heath problem.

\section{Attachment Based Family Therapy (ABFT)}

ABFT is the first manualized, empirically-based, family therapy (i.e., 12 to 16 week) designed and developed specifically to target family processes associated with youth depression and suicide. The treatment is informed by interpersonal theories of depression (Coyne, 1976; Gotlib \& Hammen, 1992, Joiner $\&$ Coyne, 1999) and focuses on factors such as parental depression (Weissman $\&$ Paykel, 1974), marital conflict, ineffective parenting practices (Cummings \& Davies, 1994), unmet attachment needs (Greenberg, 1999), loss (Harris et al., 1986) and negative parent-child interactions (Asarnow et al., 1993) as etiological and reinforcing factors of depression and suicidal behavior. ABFT is also rooted in Structural Family Therapy (Minuchin \& Fishman, 1983), Multidimensional Family Therapy (Liddle \& Hogue; 2000) and Emotion Focused Therapy (Johnson, 1996), and shares many of their conceptualizations and intervention strategies.

The primary conceptual framework organizing the treatment is attachment theory and research (Allen et al., 1998; Kobak \& Sceery, 1988). Treatment aims to specifically target important attachment processes; a) increase parental availability and emotional attunement; b) help youth resolve experience of loss or trauma (defined broadly), and c) help youth revise their negative expectancies for parental availability by improving communication and problem-solving in the parent-youth dyad. This reparative function rests on the principle that attachment models or expectancies are open to revision based on new experience across the life span (Bowlby, 1969). Most of the evidence for change in attachment organization is from studies that have examined the negative effect of stressful life events on attachment security (Kobak et al., 2006). However, the possibility of positive effects on attachment organization has also been proposed (Main \& Goldwyn, 1988). Increased security can result from later secure relationships with a romantic partner or a therapist and this speculation is supported by large sample studies that find that the high sensitivity in caregiving in early childhood can erase the effects of anxious attachment during infancy (Belsky \& Fearon, 2002). This is the explicit goal of Attachment based family therapy; to improve parent-youth communication and the youth's attachment security or confidence in the parent's availability and support. 


\section{Model of family contribution to youth suicidal behavior}

According to the model underlying ABFT, family conflict in general and lack of confidence in a caregiver's availability and responsiveness, specifically, puts a youth at risk for suicide behavior through three purported pathways (Figure 1). The first purported pathway is through hopelessness and low self-esteem that are key psychological features of depression. When parents reject, criticize, argue with and exhibit low levels of care for their child, the child becomes vulnerable to depression (Sheeber, et al., 2001).

Depression can make these youth more susceptible to suicidal ideation in order to escape these negative mood states (Baumeister, 1990).

A second purported pathway is predicated on the important role that youthparent conversation has in facilitating the development of essential, interpersonal cognitive-emotional skills, such as perspective taking, emotion regulation, impulse control, problem solving, etc. Observational studies have operationalized dyadic security as a) a cooperative resolution of goal-conflicts and b) parents tolerance for allowing adolescents' to have and express their opinion during these conversations - a core affect regulation and problem solving skill (Kobak et al., 1993; Roisman et al., 2001). Deficits in these skills are all important risk factors for suicidal behavior (Williams 2005; Linehan, 1993). Without interaction with parental role model and facilitators of these skills, youth are denied the important family development context where interpersonal problem solving and emotion regulation is learned; skills that can buffer against suicidal thinking and behavior.

A third purported pathway is through a breakdown in the protective function of the attachment bond. More specifically, a lack of confidence in a caregiver's availability leads youth to feel less able to use their caregiver as a source of safety or protection. Consequently, the youth feels unable to turn to her/his family for support when coping with suicidal ideation, victimization, school failure, or other life challenges. Having important bonds to other people that are important and meaningful is an intrinsic human

Figure 1: Model of Family Contribution to Youth Depression and Suicidal Behavior

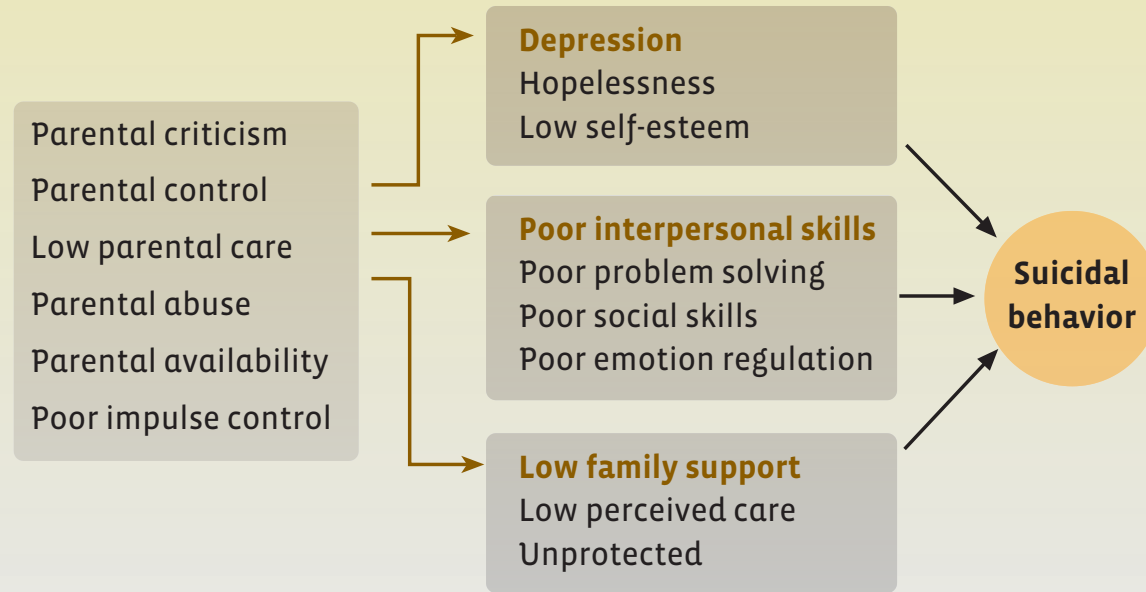

need, and thwarted belongingness is a risk factor for suicidal behavior (Joiner, 2005). The lack of family support places the youth at greater risk for suicidal ideation.

In the light of these purported risk pathways, ABFT focuses on reducing parental criticism and control and increasing parental care and monitoring which, in turn, is intended to improve the quality of the youth-parent attachment relationship. Once the attachment relationship has been improved, it serves as a secure base from which youth learn to understand and express their emotions and thoughts (including their suicidal ideation) in a differentiated and regulated manner, problem solve, obtain developmentally appropriate support and feel cared about and worthwhile. In some cases, the repaired youth-parent attachment relationship also provides a context for reworking or processing prior traumatic events (e.g., death of a family member, abandonment at the hands of a caregiver, childhood abuse, etc.). Furthermore, once parents are perceived as caring and autonomy granting, they are better positioned to guide and support their youth as she/he navigates the challenges of school, peer relations and other life domains. To accomplish these goals, there are five ABFT treatment tasks. Each task may take one or several sessions. These sessions may be alone with the youth or parent(s) or conjoint.

\section{The Clinical Model}

The Relational Reframe Task (Diamond \& Siqueland, 1998) is designed to shift the focus of the therapy away from negative, critical parental attributions of the youth (i.e., "stubborn," "disobedient" or "closed down"), which fuel youth anger and withdrawal, and onto the quality of the youth-parent relationship. Youth are typically asked "Why don't you go to your parents when you are feeling suicidal?" This question shifts the focus of therapy from fixing the youth to repairing the relational ruptures that have damaged trust in the family. If trust does not exist, youth will not engage in open, honest conversation with their parents about their suicidal ideation or their feelings and experiences in general.

The Alliance Building Task with the Youth focuses on strengthening treatment engagement and building hope for change. With the youth alone, the session focuses on strengthening patient-therapist trust, identifying core family dynamics that fuel conflict, and encouraging the youth to discuss these issues with a parent. The essential goal of this task is to gain the youth's agreement to engage in open, honest conversation with their parent(s) and to prepare the youth for such in-session enactments.

The Alliance Building Task with the Parent focuses on reducing parental distress and improving parenting practices. This begins with a supportive exploration of stressors affecting the parent (e.g., 
psychiatric distress, marital problems) as well as examining parents' own attachment loses and how that affects their parenting. When parents experience empathy for their own vulnerabilities, they become more empathic toward their youth's struggles. In this softened state, they become more receptive to learning parenting skills that focus on affective attunement and emotional facilitation (Gottman et al., 1996).

The Reattachment Task culminates the work in earlier sessions. In-session conversations between youth and parent focus on past and present experiences, thoughts and feelings which have violated the attachment bond and damaged trust. These attachment ruptures may result from a) stress due to the youth's depression, b) a history of negative interactions and communication, c) abuse, neglect, abandonment and or d) paren tal psychopathology. Regardless, when reattachment episodes are successful, parents respond to their youth's pain, accusations, anger, and or hurt in a supportive, understanding, non-defensive manner. Such responses can have a positive influence on the youth's confidence in their parent's availability and enhance reliance on the parent as a caregiver. Cognitively, the youth learns to perceive their parent as caring, interested, able to tolerate their pain and anger, and able to offer support and validation. This can lead to a restructuring of youth's schemas regarding self and other (i.e., parents). Emotionally, the opportunity for the youth to engage in sustained conversations about his/her negative feelings increases their ability to articulate, differentiate between, and regulate their emotions. Finally, these kinds of conversations increase tolerance for conflict and increase parent youth trust. As the felt security increases, the youth will more likely turn to parents for help the next time they feel suicidal and/or depressed, rather than withdraw, isolate or self harm.

The last task, the Competency Promoting Task, aims to use the renewed youth-parent relationship to facilitate the youth's involvement and success in extra-familial, prosocial contexts (e.g., school, employment, peer relations, sports). Parents are taught to encourage, support and advocate for their child as she/he navigates life's challenges. Problemsolving skills training has been a valuable component in other treatment approaches, but is rarely done in a family context where collaboratively resolving problems can also be attachment building. Furthermore, successful problem solving and success in school, peer relationships, etc. builds a sense of competency and increases positive experiences, which can buffer against further hopelessness, depression and suicidal ideation (Dumont \& Provost, 1999). Table 1 below lists the central ABFT treatment targets, the change oriented tasks/interventions, and the expected outcome.

\section{Empirical support for ABFT}

To date, four studies have demonstrated ABFT to be effective for reducing depression and suicide ideation. Thus, ABFT has been designated as a "promising" empirically supported intervention (DavidFerdon \& Kaslow, 2008). The first study, an open trial showed that ABFT was effective in reducing depres-sion and suicidal ideation (Diamond, et al., 2003).
The second study randomized 32 youth to 12 weeks of ABFT or a wait- list control condition. These youth met criteria for a major depressive disorder (MDD) Planned comparisons (group X time) indicated that, compared to the 6-week waitlist, 12 weeks of ABFT was associated with significant reduction in depression, anxiety, and family conflict. ABFT also yielded nearly significant changes in attachment to mother, hopelessness and suicidal ideation in comparison to the control group. Given that adolescents with imminent suicidal behavior were excluded (due to the waitlist condition), only 3 out of 16 adolescents randomized to ABFT met a critical level of suicidal ideation on the Suicide Ideation Questionnaire. None of these 3 adolescents met criteria for imminent suicidal behavior at the end of treatment.

After being on the wait list, these patients received treatment. Of all treated cases, $32 \%$ reported a clinically signifi-cant level of suicidal ideation at intake and only $12 \%$ reported such ideation at post-treatment. There was a significant change overall on the total SIQ score from a mean of 34 pre-treatment

Table 1: Targeted risk factors, relevant treatment task and expected outcomes.

\begin{tabular}{|l|l|l|}
\hline Treatment target & Interventions & Expected outcome \\
\hline $\begin{array}{l}\text { Parental criticism } \\
\text { and blame }\end{array}$ & Relational reframe & $\begin{array}{l}\text { Increase parental availability and empathy } \\
\text { for youth's distress. }\end{array}$ \\
\hline $\begin{array}{l}\text { Youth hopelessness } \\
\text { and disengagement } \\
\text { from parent }\end{array}$ & $\begin{array}{l}\text { Alliance building } \\
\text { with Youth }\end{array}$ & $\begin{array}{l}\text { Build treatment bond with youth, engage youth } \\
\text { in the treatment process, preparation for } \\
\text { reattachment episodes. }\end{array}$ \\
\hline $\begin{array}{l}\text { Parental stress and } \\
\text { preoccupation }\end{array}$ & $\begin{array}{l}\text { Alliance building } \\
\text { with Parents }\end{array}$ & $\begin{array}{l}\text { Build treatment bond with parent, increase } \\
\text { parental awareness of youth attachment needs, } \\
\text { establish reattachment as treatment goal, } \\
\text { preparation for reattachment episodes. }\end{array}$ \\
\hline $\begin{array}{l}\text { Youth-parent } \\
\text { disengagement and } \\
\text { conflict }\end{array}$ & $\begin{array}{l}\text { Reattachment } \\
\text { Episodes }\end{array}$ & $\begin{array}{l}\text { Increase youth's perceptions of parent's avail- } \\
\text { ability and protection, increase youth's confi- } \\
\text { dence in communicating goals and needs. } \\
\text { Work through memories of loss and abuse, }\end{array}$ \\
\hline $\begin{array}{l}\text { Poor youth functi- } \\
\text { improve affect regulation. } \\
\text { familial contra- }\end{array}$ & $\begin{array}{l}\text { Promote parental } \\
\text { support for youth } \\
\text { competency and } \\
\text { exploration }\end{array}$ & $\begin{array}{l}\text { Increase use of the parent as a secure base } \\
\text { for developing new skills and competence } \\
\text { in peer and school contexts. }\end{array}$ \\
\hline
\end{tabular}




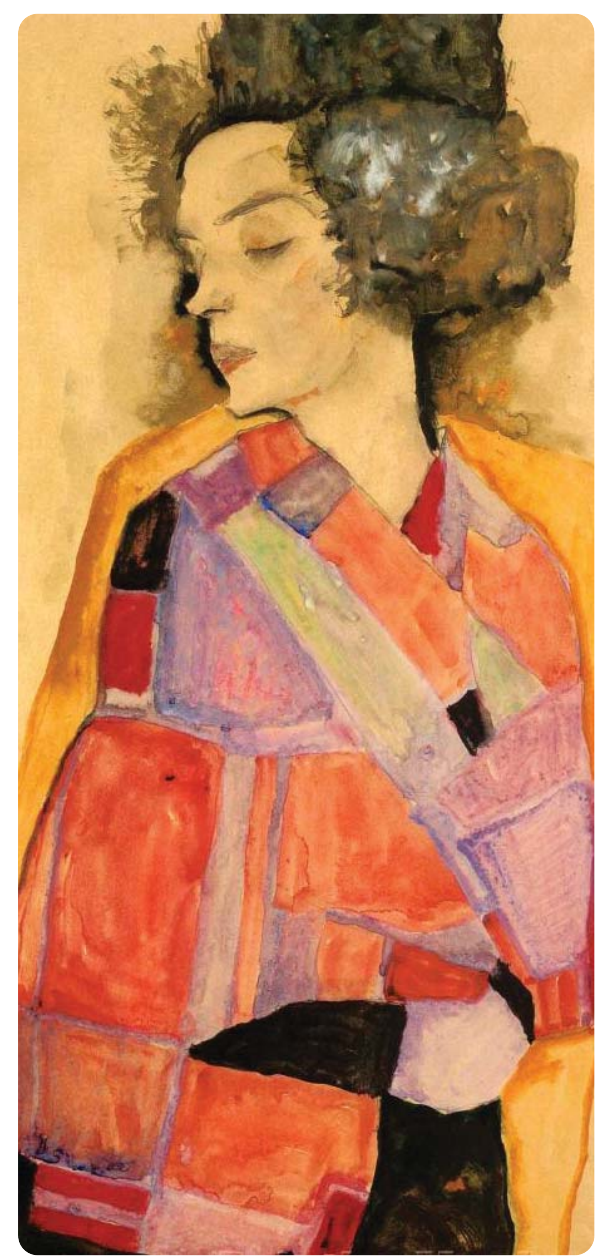

Egon Schiele, "Daydreamer"

to a mean of 21 post-treatment for the treated sample as a whole, far below the established clinical cut of 31. ES for many of these parameters were promising. The full report of these findings can be found in Diamond et al. (2002).

A third study was funded by the Centers for Disease Control and Prevention to reduce suicide ideation (Diamond et al., 2010). Sixty-six youth with clinical levels of suicidal ideation and elevated depression were randomized to ABFT or Enhanced Usual Care (EUC). Elevated depression was used as inclusion criteria to help identify with a higher severity. Only 50\% met criteria for major depression disorder. Compared to EUC $(\mathrm{M}=16.2,95 \% \mathrm{CI}, 10.1-22.2)$, youth treated with ABFT $(\mathrm{M}=5.2,95 \% \mathrm{CI}$, 1.6-8.8) had significantly greater and faster reductions in suicidal ideation during treatment. These differences persisted at follow-up (ABFT M=10.4; 95\% CI, 5.6-15.2; EUC M=23, 95\% CI, 15.6$30.4)$ with a large effect size $(E D=.97)$. ABFT was also associated with significantly higher rates of clinical recovery on suicidal ideation at all time points with a strong effect size $(\mathrm{OR}=4.41)$. These findings persisted when looking at the subgroup of youth who met criteria for Major Depressive Disorder (i.e., a more severe population). Finally, ABFT retained patients in treatment much longer (9.7 sessions) compared to usual care (2.9 sessions). This is important for a population that notoriously does not attend or drops out of treatment prematurely.

There has been growing interest in more targeted sub group populations. For example, subjects with depression and or suicide and a history of sexual or physical abuse have been treatment resistance, especially when treated with CBT (Asarnow et al, 2009; Barbe, et al., 2004; Lewis et al., 2010). In contrast, Adolescents with a history of sexual abuse who received ABFT had significantly lower suicidal ideation $($ mean $=7.94$, $\mathrm{SD}=12.09)$ than those who received EUC (mean=13.73, SD=10.15, $\mathrm{p}=.05)$ (Creed, et al, under review). There is also growing interest in Gay, lesbian, Bisexual youth, given that they are at high risk for suicide. In new pilot research, ABFT was shown to be very successful in engaging and treating this population as well (Diamond, et al, under review). We have just completed a study using ABFT as an after care treatment for youth leaving the hospital after a suicide attempt. Patients remained in treatment for the full 16 weeks retained gains made while in the hospital. (Diamond et al, manuscript in preparation).

Recently, a small-scale RCT study ( $\mathrm{n}=$ 20) was conducted in Stavanger, Norway. Three therapists that were trained by the developers of ABFT treated 11 patients (ABFT). Compared with patients that received treatment as usual (TAU, $n=$ 9), ABFT had clinically significant symptom reduction using independent raters (Hamilton Depression Rating Scale) with high effect size $(E S=1.08)$ and high retention in treatment (Israel $\&$ Diamond, 2010). Despite a small sample size, implementation and administrative shortcomings, this study showed that ABFT can be transported to Scandinavia, taught to Norwegian therapists, and has potential to treat Norwegian youth. In all the above studies only a very small percentage of adolescents used anti-depressants. They were required to be stable on the drug and still meet study criteria before beginning the trial. Together, these findings suggest that the utility and external validity of ABFT is promising.

\section{Conclusion}

ABFT targets key intrapersonal and interpersonal elements that are often associated with youth suicide. Family factors play a key role for young people and focusing on the family is a promising alternative to the existing individual and group therapy models for this population. ABFT has good support for youth with severe suicide ideation, even if they are depressed, have a history of sexual abuse, or have an alternative sexual orientationfactors that have been associated with poor treatment outcome. A pilot study suggests that therapist in Norway can learn and use this model. However, we need studies with larger samples sizes and stronger control conditions to be more confident of this innovative treatment modality. Still, given the dearth of effective treatments for suicidal youth, the scientific results and theoretical frame work is encouraging.

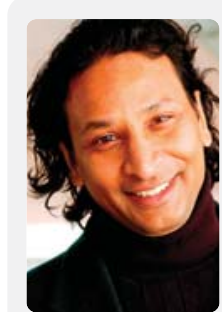

Pravin Israel er psykologspesialist og seniorforsker ved FoU-avdeling Psykisk Helsevern, Akershus Universitetssykehus (Ahus). Han har mange års erfaring fra klinisk arbeid med barn og familier, noe som har inspirert hans forskning. Avsluttet nylig en RCT-studie om tilknytningsbasert familieterapi for deprimerte ungdommer og koordinerer en forskergruppe ved Ahus som har depresjon hos barn og ungdom som sitt satsingsområde. Videre er han involvert i forskningsevaluering av en storstilt nasjonal implementering av Assertive Community Treatment (ACT) i Norge. 


\section{References}

Allen, J. P., Moore, C., Kuperminc, G., \& Bell, K (1998). Attachment and adolescent psychosocial functioning. Child Development, 69(5), 1406-1419. American Academy of Child and Adolescent Psychiatry. (2001). Facts for families \# 10: Teen suicide. Accessed 29.11.10.http://www.aacap.org/publications/factsfam/ suicide.htm

Asarnow, J. R., Goldstein, M. J., Tompson, M., \& Guthrie, D. (1993). One-year outcomes of depressive disorders in child psychiatric in-patients: evaluation of the prognostic power of a brief measure of expressed emotion. J Child Psychol.Psychiatry, 34, 129-137.

Asarnow, J.R., Emslie, G., Clarke, G., Wagner, K.D., Spirito, A., Vitiello, B.,Brent, D. (2009). Treatment of selective serotonin reuptake inhibitor-resistant depres sion in adolescents: predictors and moderators of treatment response. Journal of the American Academy of Child Adolescent Psychiatry, 48,330-339.

Asarnow, J.R., Goldstein, M.J., Tompson, M., \& Guthrie, D. (1993). One-year outcomes of depressive disorders in child psychiatric in-patients: evaluation of the prog nostic power of a brief measure of expressed emotion. Journal of Child Psychology and Psychiatry, 34, 129-137. Barbe, R., Bridge, J., Birmaher, B., Kolko, D., \& Brent D. (2004). Lifetime history of sexual abuse, clinical presentation, and outcome in a clinical trial for adole scent depression. Journal of Clinical Psychology, 65, 77-83. Baumeister, R. F. (1990). Suicide as escape from self. Psychological review, 97, 90-113.

Beautrais, A.L., Joyce, P.R., \& Mulder, R.T. (1996). Risk factors for serious suicide attempts among youths aged 13 through 24 years. Journal of the American Academy of Child \& Adolescent Psychiatry, 35, 1174-1182.

Belsky, J., \& Fearon, R.M.P. (2002). Early attachment security, subsequent maternal sensitivity, and later child development: Does continuity in development depend upon continuity of caregiving? Attachment \& Human Development, 4, 361-387.

Bowlby, J. (1969). Attachment. London: Hogarth. Brent, D. A., Perper, J. A., Goldstein, C. E., Kolko, D. J., Allan, M. J., Allman, C. J. et al. (1988). Risk factor for adolescent suicide. A comparison of adolescent suicide victims with suicidal inpatients. Arch.Gen.Psychiatry, 45, 581-588.

Brent, D.A., Perper, J.A., Moritz, G., \& Liotus, L. et al (1994). Familial risk factors for adolescent suicide: A case-control study. Acta Psychiatrica Scandinavica, $89,52-58$.

Connor, J. J., \& Rueter, M. A. (2006). Parent-child relationships as systems of support or risk for adolescent suicidality. Journal of Family Psychology. 20(1), 143-155. Coyne, J.C. (1976). Depression and the response of others. Journal of Abnormal Psychology, 85, 186-193. Creed, T.A., Gillham, J., Gallop, R., Hamilton, J., \& Diamond G.S. (2011). Impact of sexual trauma history on attachment-based. (Manuscript under review).

Cummings, E. M. \& Davies, P. T. (1994). Maternal depression and child development. J Child Psychol Psychiatry, 35, 73-112.

David-Ferdon, C. \& Kaslow, N.J. (2008). Evidence based psychosocial treatments for child and adolescent depression. Journal of Clinical Child and Adolescent Psychology, 37, 62-104.

Diamond, G., Siqueland, L., \& Diamond, G.M. (2003). Attachment-based family therapy for depressed adolescents: programmatic treatment development. Clinica Child and Family Psychology Review, 6, 107-127.

Diamond, G.D. \& Levy, L. (2011). Attachment based family therapy: psychaitric hospital after care for suicidal youth. (mansuscript in preperation).
Diamond, G.M, Diamond, G.S., Suzanne Levy, S.L., Closs, C., Ladipo, T., \& Siqueland, L., (2011). Attachment-based family therapy for suicidal lesbian, gay and bisexual adolescents: A treatment development study. Manuscript under review

Diamond, G.S., \& Siqueland, L. (1998). Emotions, attachment and the relational reframe: The first session. Journal of Systemic Therapies, 17(2), 36-50. Diamond, G.S., Reis, B.F., Diamond, G.M., Siqueland, L., \& Isaacs, L. (2002). Attachment-based family therapy for depressed adolescents: a treatment development study. Journal of the American Academy of Child \& Adolescent Psychiatry, 41, 1190-1196.

Diamond, G.S., Wintersteen, M.B., Brown, G.K., \& et al. (2010). Attachment-based family therapy for adolescents with suicidal ideation: A randomized controlled trial. Journal of the American Academy of Child \&

Adolescent Psychiatry, 49, 122-131.disorder. New York: Guilford Press.

Dumont, M., \& Provost, M.A. (1999). Resilience in adolescents: Protective role of social support, coping strategies, self-esteem, and social activities on experience of stress and depression. Journal of Youth and Adolescence, 28, 343-363.

Fergusson, D. M., Woodward, L. J., \& Horwood, L. J. (2000). Risk factors and life processes associated with the onset of suicidal behaviour during adolescence and early adulthood. Psychological Medicine, 30, 23-39. Gotlib, I.H., \& Hammen, C.L. (1992). Psychological aspects of depression : toward a cognitive-interpersonal integration. Chichester: J. Wiley.

Gottman, J.M., Katz, L.F., \& Hooven, C. (1996).

Parental meta-emotion philosophy and the emotional life of families: Theoretical models and preliminary data. Journal of Family Psychology, 10(3), 243-268.

Greenberg, L.S. (1999). Ideal psychotherapy research: a study of significant change processes. Journal of Clinical Psychology, 55. 1467-1480.

Grunbaum, J. A., Kann, I., \& Kinchen, S. A. (2002). Youth Suicide Risk Behavior Surveillance - United States. MMWR CDC Surveillance Summary 51[SS4], 1-64: 2001.

Harrington R, Kerfoot M, Dyer E, et al. (1998). Randomized trial of a home-based family intervention for children who have deliberately poisoned themselves. J Am Acad Child Adolesc Psychiatry.;37(5):512-518.

Harris, T., Brown, G.W., \& Bifulco, A. (1986). Loss of parent in childhood and adult psychiatric disorder: the role of lack of adequate parental care. Psychol Med, 16, 641-659.

Huey S.J, Henggeler S.W. Rowland M.D, et al. (2004). Multisystemic therapy effects on attempted suicide by youths presenting psychiatric emergencies. J Am Acad Child Adolesc Psychiatry, 43(2):183-190.

Israel, P., \& Diamond, G.S. (2011). Feasibility of attach ment based family therapy for depressed youth referred to Norwegian specialty mental health services. Submitted for publication.

Johnson, S.M. (1996). The practice of emotionally focused marital therapy: Creating connection. The practice of emotionally focused marital therapy: Creating connection. Philadelphia, PA, US: Brunner/Mazel, US. Joiner, T. E. (2005). Why people die by suicide. Harvard University Press.

Joiner, T.E., Coyne, J.C. (1999). The Interactional nature of depression: advances in interpersonal approaches. Washington, D.C.: American Psychological Association.

Kerr, D. C. R., Preuss, L. J., \& Kind, C. A. (2006). Sui cidal adolescents' social support from family and peers: Gender-specific associations with psychopathology. Journal of Abnormal Child Psychology. 34(1), 103-114.
Kobak, R. R., \& Sceery, A. (1988). Attachment in late adolescence: Working models, affect regulation, and representations of self and others. Child Development, 59(1), 135-146.

Kobak, R. R., Cole, H. E., Ferenz-Gillies, R., Fleming, W. S., \& Gamble, W. (1993). Attachment and emotion regulation during mother-teen problem solving: a control theory analysis. Child Dev., 64, 231-245.

Kobak, R., Cassidy, J., Lyons-Ruth, K., \& Ziv, Y. (2006). Attachment, stress, and psychopathology: A developmental pathways model. Cicchetti, Dante [Ed], Cohen, Donald J [Ed]. Developmental psychopathology, Vol 1: Theory and method (2nd ed.). Hoboken, NJ, US: John Wiley \& Sons Inc, US; pp. 333-369.

Kurtz, L., \& Derevensky, J. L. (1993). Stress and coping in adolescents: The effects of family con-figuration and environment on suicidality. Canadian Journal of School Psychology, 9, 204-216.

Lewis, C.C., Simons, A.D., Nguyen, L.J., Muakami, J. L., Reid, M. W., Silva, S. G. \& March, J. S. (2010).

Impact of childhood trauma on treatment outcome in the treatment for adolescents with depression study (TADS). Journal of the American Academy of Child Adolescent Psychi-atry, 29,132-140.

Liddle, H.A., \& Hogue, A. (2000). A family-based, developmental-ecological preventive intervention for high-risk adolescents. Journal of Marital and Family Therapy, 26, 265-279.

Linehan, M. (1993). Cognitive-behavioral treatment of borderline personality

Main, M., \& Goldwyn. (1998). Adult attachment scoring and classification system. Unpublished manuscript, University of California, Department of Psychology.

Minuchin, S., \& Fishman, H.C. (1979). The psychosomatic family in child psychiatry. Journal of the American Academy of Child \& Adolescent Psychiatry, 18, 76-90.

Roisman, G.I., Madsen, S. D., Hennighausen, K. H., Sroufe, L. A., \& Collins, W. A. (2001). The Coherence of Dyadic Behavior across Parent-Child and Romantic Relationships as Mediated by the Internalized Representation of Experience. Attachment \& Human Development, 3(2), 156-167.

Rutter, M., \& Quinton, D. (1984). Parental psychiatric disorder: Effects on children. Psychological Medicine, 14, 853-880.

Sheeber, L., Hops, H., \& Davis, B. (2001). Family processes in adolescent depression. Clinical Child and Family Psychology Review, 4, 19-36.

Spirito A, Stanton C, Donaldson D, \& Boergers J. (2002). Treatment-as-usual for adolescent suicide attempters: Implications for the choice of comparison groups in psychotherapy research. J Clin Child Adolesc Psychol., 31(1):41-47.

Tarrier, N., Taylor, K., \& Gooding, P. (2008). Cognitivebehavioral interventions to reduce suicide behavior: A systematic review and meta-analysis. Behavior Modification, 32(1), 77-108.

The Norwegian Institute of Public Health (2010). Norgeshelsa. Accessed 29.11.10. http://www. norgeshelsa.no/norgeshelsa/.

Wagner, B. M., Silverman, M. A. C., \& Martin, C. E. (2003). Family factors in youth suicidal behaviors. American Behavioral Scientist. Special Issue: Suicide in Youth. 46(9), 1171-1191.

Weissman, M.M., \& Paykel, E.S. (1974). Use of special studies: The treatment of suicidal behavior. Riedel, Donald C [Ed], Tischler, Gary L [Ed], Myers, Jerome K [Ed]. Patient care evaluation in mental health programs. Oxford, England: Ballinger, England.

Williams J.M.G., Barnhofer T., Crane C., \& Beck A.T. (2005). Problem solving deteriorates following mood challenge in formerly depressed patients with a history of suicidal ideation. Journal of Abnormal

Psychology,;114: 421-31 